\title{
Hydrological modelling of glacierized catchments focussing on the validation of simulated snow patterns - applications within the flood forecasting system of the Tyrolean river Inn
}

\author{
J. Schöber ${ }^{1,2}$, S. Achleitner ${ }^{3}$, R. Kirnbauer ${ }^{4}$, F. Schöberl ${ }^{2}$, and H. Schönlaub ${ }^{5}$ \\ ${ }^{1}$ alpS - Centre of Natural Hazard Management, Innsbruck, Austria \\ ${ }^{2}$ Institute of Geography, University of Innsbruck, Innsbruck, Austria \\ ${ }^{3}$ Unit of Hydraulic Engineering, University of Innsbruck, Innsbruck, Austria \\ ${ }^{4}$ Institute for Hydraulic and Water Resources Engineering, Vienna University of Technology, Vienna, Austria \\ ${ }^{5}$ TIWAG - Tiroler Wasserkraft AG, Innsbruck, Austria
}

Received: 19 January 2010 - Revised: 3 June 2010 - Accepted: 9 June 2010 - Published: 28 September 2010

\begin{abstract}
The catchment of the river Inn is located in the Swiss and Austrian Alps. In the frame of the flood forecasting system "HoPI" (Hochwasserprognose für den Tiroler Inn), the Austrian part of the river Inn and its tributaries are covered within a hybrid numerical model. The runoff from the glacierized headwaters of the south-western Inn tributaries is calculated using the Snow- and Icemelt Model "SES" which utilizes a spatially-distributed energy balance approach; within SES, the accumulation and melting processes for snow, firn, and ice are considered. It is of great importance that such a type of model is used in the simulation of alpine areas since in these regions stream flow is influenced by the accumulation and melt of snow and ice and snow-free glaciers have also the potential to increase or even induce flood flow. For a prototype of the forecast system, SES was calibrated using the snow depletion of a glacier, but later, following the first results during the operational mode, the model was recalibrated and validated using remotely-sensed data covering all 13 glacierized catchments. Using the final snow-parameter setting, a simulation run of 15 hydrological years without any state corrections achieved overall agreements between observed and simulated snow cover ranging from $68 \%$ to $88 \%$ for all individual catchments. Runoff was calibrated and validated using the data from three different gauges. A parameter set, including both validated snow and runoff parameters, was applied for the modelling of a fourth gauged catchment and also achieved accurate results. This final unique parameterization was transferred to the remaining, ungauged watersheds.
\end{abstract}

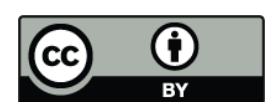

Correspondence to: J. Schöber (schoeber@alps-gmbh.com)

\section{Introduction}

This article is focused on the hydrological modelling of the glacierized parts of the Ötztaler Ache and its adjacent river basins. These mountain ranges contain some of the largest glaciers in Austria; e.g., the Ötztaler Ache catchment $\left(893 \mathrm{~km}^{2}\right)$ with a glacierization rate of $13 \%$ is one of the main tributaries to the river Inn. Floodwaters from glacierized alpine regions can be caused by heavy rainfall runoff, meltwater discharge, or the outburst of ice-dammed lakes (Braun and Weber, 2002). The major flood event in this region in recent history occurred on 25 August 1987 and was caused by heavy amounts of precipitation. Due to a snowline at around $3500 \mathrm{~m}$ most of the precipitation was introduced in liquid form. The severity of this event was additionally increased because of the snow free Ötztal mountain ranges in August 1987. Rainfall acting on a predominantly snow-free glacierized area results in a rapid runoff generation similar to mainly sealed surfaces (Steinacker, 1988). Consequently, water is discharged almost without delay as observed during the main flood event on the glacier Vernagtferner in August 1998 (Braun and Weber, 2002). As well as their role in flooding processes, glaciers also have a major influence on the overall runoff regime of glacierized catchments: e.g., the mean annual contribution of ice melt to total runoff for gauging stations along the Ötztaler Ache derived from model results is between $37 \%$ and $27 \%$ (Innsbruck/Inn 8.4\%) with a contribution up to $50 \%$ during summer months (Weber et al., 2009).

Thus, when dealing with hydrological modelling in glacierized areas, the model used should be able to account for situations with and without snow coverage. The consideration of rainfall runoff generation and its superposition

Published by Copernicus Publications on behalf of the European Geosciences Union. 
with melting runoff is a clear requirement for modelling in such areas. Distributed energy balance models have a long tradition in glacier hydrology (e.g. Escher-Vetter, 1980; Strasser et al., 2004), but in recent years the use of distributed temperature index models (Hock, 1999) has become more widespread, especially in alpine flood forecasting systems (e.g. Jasper et al., 2002; Verbunt et al., 2007). The temperature-index approach parameterizes the physical background of the snowmelt. In contrast, physically-based models, such as energy-balance based snow models, try to describe the physics behind the snow and ice melt processes. All model types are usually calibrated using observed flow hydrographs with special focus on particular flood events (e.g. Viviroli et al., 2009). Fully distributed energy-balance snow models, such as the SES used here, also give the opportunity for using spatially distributed snow-cover data for calibration purposes. Blöschl et al. (1989) presented an approach of evaluating a distributed model of an alpine catchment using rectified aerial photographs. During the development of the forecast system, snow-depletion patterns calculated by SES were evaluated with rectified terrestrial photos of the glacier Vernagtferner (Asztalos et al., 2007). For taking the varying behaviour of different regions into account, the calibration using spatially distributed data was extended to the total SES-modelling area of $460 \mathrm{~km}^{2}$. However, the rectifying-process of either aerial or terrestrial taken photographs is time-consuming and therefore limited in usage for large scale snow modelling. In contrast, space-borne datasets can be the source of area-wide snow depletion patterns and satellite-based methods are commonly used for estimating snow cover characteristics (e.g. Hall et al., 1987; Dozier, 1989). Since satellite data can have limitations because of low repetition rates and high cloud cover (Blöschl and Kirnbauer, 1992), an additional data source is introduced in this paper. A 3-D-comparison of the simulation results with terrestrial photos is used as proxy-data source during the operational mode of the flood forecasting system, where sometimes quick information on the present state of a catchments state is needed.

\section{Methods}

\subsection{Data and model description}

\subsubsection{HoPI}

The Inn River Forecasting System was developed on behalf of the Tyrolean State Government and TIWAG (Tyrolean Hydropower Company). The hybrid forecasting system consists of different modules: 1) data management and preprocessing, 2) hydrology (glaciated and non-glaciated parts using SES and HQsim, respectively), 3) hydraulics, and 4) browser-based user interface. Observed and simulated runoff information is available along the Inn river and as well as for its tributaries. The whole system operates in real time on an hourly basis having direct access to remote transmitted meteorological and hydrological data. An overview of the development of the flood forcasting system can be found in Kirnbauer et al. (2009), Asztalos et al. (2007), and Kirnbauer and Schönlaub (2006).

The product INCA (Integrated Nowcasting through Comprehensive Analysis) provides the meteorological input during the forecast period until $+48 \mathrm{~h}$. The data set consists of all required input parameters. The meteorological forecast data is already provided as spatially distributed data set to a $1 \mathrm{~km}$ grid (Haiden et al., 2007).

A complete HoPI simulation run can be performed automatically using either the web-based user interface or the command line system as an alternative. In a first step, the local database of observed meteorological and hydrological data is updated. The data in the Tyrolean region is originally provided from a number of different institutions, then all the datasets are cumulated and provided via the Tyrolean hydrological service. The latest available INCA forecast sets are obtained the same way. Both the measured and forecast data is spatially interpolated onto a $5 \mathrm{~km} \times 5 \mathrm{~km}$ grid that covers the whole Inn catchment. Rainfall is interpolated using the inverse distance method with quadratic distance weights. Temperature is transferred to different sub-catchments depending on their elevation. Base temperature and laps rate are calculated time-step wise on a regional basis (Rinderer et al., 2008).

The prepared meteorological input data is provided to the hydrological components of the software package. The whole system comprises of the hydrological components SES and HQsim (Kleindienst, 1996) for the simulation of glacierized $\left(460 \mathrm{~km}^{2}\right)$ and non-glacierized areas $\left(6290 \mathrm{~km}^{2}\right)$, respectively (Fig. 1). The discharges of all hydrological models are used as input for the hydraulic model of the river Inn, which is realized in the 1-D-hydrodynamic model Flux $^{D S S / D E S I G N E R} /$ FLORIS $^{2000}$ (Reichel et al., 2000).

\subsubsection{SES}

The SES model (Schnee und Eis Schmelzmodell - snow and glacier melt model; Asztalos et al., 2007; Asztalos, 2004), used for the flow modelling of the glacierized headwaters, is a fully-distributed energy balance based model. The model, designed for long-term water balance and runoff simulations, is one of the key components within the flood forecasting system of the river Inn. Energy balance models allow the integration of measurable physical quantities, such as the albedo of a surface facies within a catchment. Therefore, they tend to increase the a priori parameterization of the processes and reduce the calibration effort and allow the transfer of experience from one catchment to another (Zappa et al., 2003). SES is a further development of the snow melt model originally developed by Blöschl et al. (1991). It is a grid-based model for calculating (1) the spatially distributed 


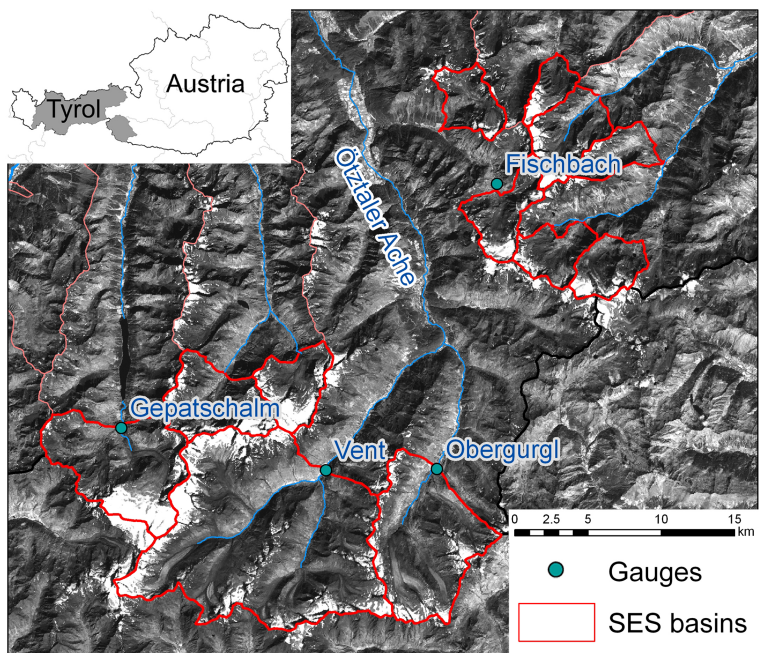

1 Vent

area $\left[\mathrm{km}^{2}\right]$

2 Obergurgl

165

3 Gepatschalm

72

4 Oberbergbach

53

5 Pitze

22

20

6 Winnebach 30

7 Fischbach 19

8 Taschachbach $\quad 16$

9 Sulzenaubach 16

10 Falbesonerbach 14

11 Fernaubach 16

12 Lüsenerbach 9

13 Jambach 13

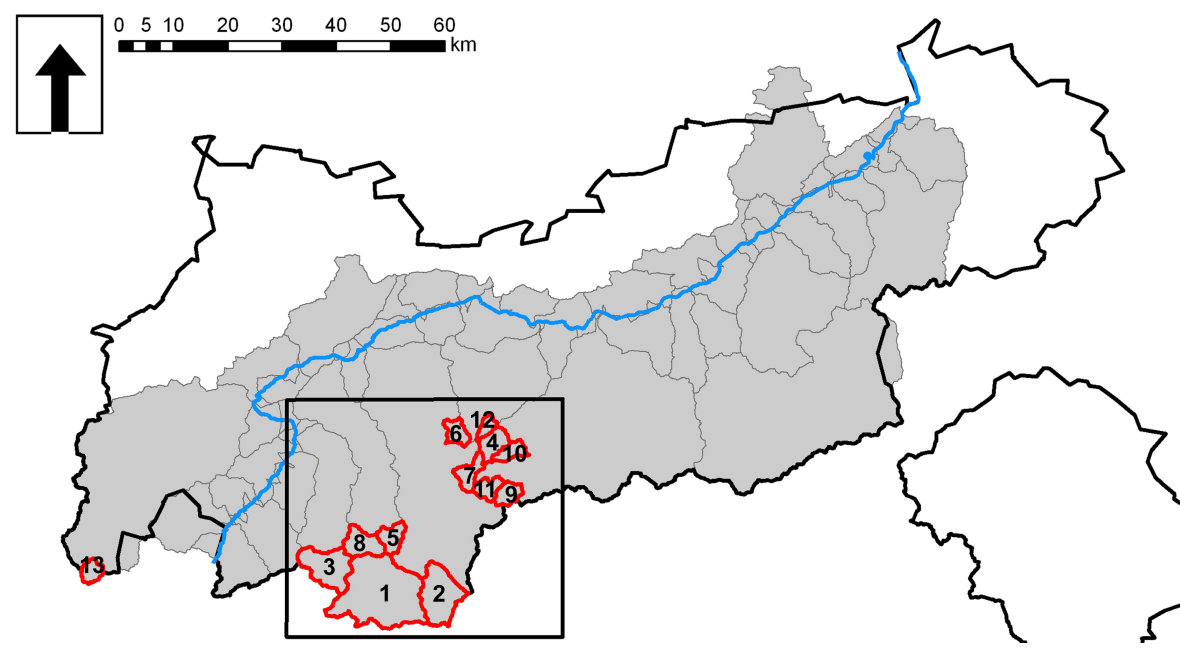

Fig. 1. Basin of the river Inn in Tyrol/Austria: tributary catchments are displayed in gray (HQsim), boundaries of the glacierized headwaters are highlighted in red (SES).

accumulation of snow and firn, and (2) the cell-wise snow, firn, and ice melt in a glacierized catchment. The melt of all model components is calculated depending on the energy balance of each grid element at hourly intervals. Topographic parameters such as elevation, slope, aspect, curvature, and local horizon are derived from a digital elevation model. Within HoPI the spatial resolution of the SES-model is $50 \mathrm{~m} \times 50 \mathrm{~m}$. Hourly meteorological input consists of air temperature, lapse rate, precipitation, relative humidity, wind speed, and global radiation. Cloudiness is estimated from measured global radiation and astronomically possible radiation using the approach of Kasten and Czeplak (1980).

The applied energy balance equation can be denoted as:

$Q=Q_{\mathrm{SW}}+Q_{\mathrm{LW}}+Q_{\mathrm{S}}+Q_{\mathrm{L}}+Q_{\mathrm{SOIL}}$

where $Q_{\mathrm{SW}}$ is the short wave balance, $Q_{\mathrm{LW}}$ is the long wave balance, $Q_{\mathrm{S}}$ is the sensible heat flux, $Q_{\mathrm{L}}$ is the latent heat flux, and $Q_{\text {SOIL }}$ is the ground heat flux. Generally, short wave radiation is the dominating source of the melt energy introduced to the alpine snow cover. Therefore, the albedo of the snow cover and the current extend of firn and/or iceexposed parts of the glacier catchment are of high importance. The albedo changes considerably with progressing metamorphosis of the snow cover and is influenced by possible pollution (e.g. Sahara dust), as well as diurnal variation which depends on the reflectivity of ice for solar radiation (Weber, 2001). In contrast to the often applied aging-curve approach of the US Army Corps of Engineers (1956), a module was developed for SES to take the temporal change of the albedo as a function of the consumed energy input into account (Asztalos, 2004). After snowfall, the albedo value of the new snow decreases according to the absorbed solar energy until the old snow albedo is reached. If no new snow is accumulated, the albedo will remain at the value of the old snow until all the snow has melted. Afterwards, the albedo decreases to the fixed albedo values of firn or ice. 
Table 1. Main characteristics of gauged glacierized catchments $(\mathrm{C}=$ Calibrated, $\mathrm{V}=$ Validated, both for discharge and snow $)$.

\begin{tabular}{lcccc}
\hline & Vent & Obergurgl & Gepatschalm & Fischbach \\
\hline Main river & Ötztaler Ache & Ötztaler Ache & Fagge & Ötztaler Ache \\
Area $\left[\mathrm{km}^{2}\right]$ & 165 & 72 & 53 & 19 \\
Glacierization [\%] & 35 & 32 & 39 & 30 \\
Elevation range [m] & $1880-3772$ & $1900-3549$ & $1920-3518$ & $2153-3477$ \\
Mean elevation [m] & 2890 & 2810 & 2841 & 2845 \\
Glacier tongue [m] & 2600 & 2700 & 2250 & 2720 \\
Calibrated/Validated & $\mathrm{C}$ & $\mathrm{C}$ & $\mathrm{C}$ & $\mathrm{V}$ \\
\hline
\end{tabular}

The incoming and outgoing long wave radiations are calculated with the Stefan-Boltzmann equation including an emission coefficient for cloudy sky which is determined using vapour pressure and cloudiness. The turbulent fluxes (sensible and latent heat fluxes) are parameterised using a wind function, where the heat transfer coefficient $\left[\mathrm{W} /\left(\mathrm{m}^{2} \mathrm{~K}\right)\right]$ and wind speed $[\mathrm{m} / \mathrm{s}]$ are included. Ground heat flux is a calibration parameter $\left[\mathrm{W} / \mathrm{m}^{2}\right]$; it is constant for non-glacierized areas and zero at glaciers. More detailed descriptions of the calculation methods of the energy balance components in SES can be found in Asztalos et al. (2007) and Kirnbauer et al. (2009).

Within SES the snowline is simulated using a lower and an upper wet bulb temperature threshold to separate snowfall from rain. The wet bulb temperature is calculated using air temperature taking into account the relative humidity. To calculate the internal processes (heat and mass fluxes) in the snow pack, an approach by Braun (1985) is used based on the concepts of water retention and cold content.

Meltwater from different areas of the (partly) glacierized catchment follows different flow paths on its way to the catchment outlet and is retained in different ways. The area is divided into four regions with temporally-changing extents: 1) non-glacierized area, 2) snow free glacier, 3) firn area, and 4) snow on the glacier. To cumulate the spatially-distributed meltwater components and to rout them towards the catchment outlet, a system of Nash-cascades (Nash, 1960) is used. The meltwater generated in a time step is summed up for the four types of areas (non-glacierized, snow free, firn and snow) and routed via four parallel linear reservoirs. An additional Nash-cascade covering the subsurface flow completes the routing systems. Each cascade is treated separately where their routing parameters are subject to calibration.

\subsection{Description of the case study area}

Within the flood forecast system 13 glacierized catchments are realized with SES with an overall area of $460 \mathrm{~km}^{2}$. The largest glacierized areas are located in the Ötztal and Stubai mountain ranges, represented by 12 SES-areas. One additional SES-area is located in the Silvretta mountain range (Fig. 1). The highest peaks of the Ötztal Mountains reach
Table 2. Final values of calibrated snow parameters.

\begin{tabular}{ll}
\hline Energy balance & \\
Albedo - New snow & $0.90[-]$ \\
Albedo - Old snow & $0.65[-]$ \\
Albedo - Firn & $0.64[-]$ \\
Albedo - Ice & $0.33[-]$ \\
Ground Heat Flux & $5\left[\mathrm{~W} / \mathrm{m}^{2}\right]$ \\
\hline Wet bulb temperature for snow/rain separation \\
Lower threshold (snow) & $0{ }^{\circ} \mathrm{C}$ \\
Higher threshold (rain) & $0.8^{\circ} \mathrm{C}$ \\
\hline
\end{tabular}

up to $3700 \mathrm{~m}$. According to the Austrian Glacier Inventory from 1997, $145 \mathrm{~km}^{2}$ of the Ötztal Mountains and $50 \mathrm{~km}^{2}$ of the Stubai Mountains are covered by glaciers (Lambrecht and Kuhn, 2007). Within the catchment of Vent direct annual glacier mass balance measurements have been made for the glacier Hintereisferner since 1953 (Fischer, 2009) and for the Vernagtferner since 1964 (Escher-Vetter et al., 2005). Similarly, long term records of runoff are available for the Vent Venterache gauge (since 1951, $165 \mathrm{~km}^{2}$ ), Vent - Rofenache gauge (since 1967, $98 \mathrm{~km}^{2}$ ) and Vernagtbach gauge (since $\left.1974,11.4 \mathrm{~km}^{2}\right)$.

\subsection{Model calibration}

Four of the total 13 glacierized catchments modelled with SES are directly gauged. The calibration of the Nash cascades has been done based on runoff data from the gauging stations of Vent - Venterache $165 \mathrm{~km}^{2}$, Obergurgl $72 \mathrm{~km}^{2}$ and Gepatschalm $54 \mathrm{~km}^{2}$ (Table 1). Snow parameters (Table 2) were calibrated using spatially-distributed snow data from these three gauged catchments. The snow calibration process included further spatially distributed data from the catchments of Winnebach $\left(16 \mathrm{~km}^{2}\right)$, Pitze $\left(20 \mathrm{~km}^{2}\right)$, and Oberbergbach $\left(22 \mathrm{~km}^{2}\right)$. For the latter catchment, webcam photos are also available. For the calibration of the snow accumulation parameters, such as the lower and the upper wet bulb temperature threshold to separate snowfall from rain, 
snow cover data was used together with snow depth measurements $[\mathrm{cm}]$ at Pitztal glacier. These measurements were compared with the value of snow water equivalent (SWE) [mm] of the respective model grid point from SES. This was arranged with the inclusion of point-wise snow density observations made in the western part of the Ötztal Mountain range (Kirnbauer et al., 2009).

\subsubsection{Runoff}

The outcome of the melt model is a routed runoff. Within HoPI the calculated discharge of the glacierized headwaters serve as input for the calculation of non-glacierized tributaries to the Inn river with HQsim. To meet the requirement of a flood forecast system, observed high discharge rates and flood events are of the highest importance during calibration. Both flow measurements and meteorological input data were continuously available since October 1994 . The whole data set was divided into a calibration period (October 1994September 2008 - past data) and a validation period (October 2008-September 2009 - online data during operational mode).

Initially the ability of the model to describe seasonal time spans was tested. Afterwards, the model results were tested for their quality to describe large flow events. For the flow event separation a semi-automated approach was used, this splits the continuous hydrograph on the basis of an adjustable discharge value (e.g. larger than the recurrence interval of one year-HQ1). Each of the events is then evaluated separately for indicators such as the measured and simulated peak flows $\left(Q_{\text {MAX,M }}\left[\mathrm{m}^{3} / \mathrm{s}\right]\right.$ vs. $\left.Q_{\text {MAX,s }}\left[\mathrm{m}^{3} / \mathrm{s}\right]\right)$, the temporal shift of the peak flow $(\Delta T[\mathrm{~h}])$, and the bias of the events discharge volume $(B[-])$. A similar approach was used in Achleitner et al. (2009).

\subsubsection{Distributed snow cover}

An alternative method to calibrate and test the snow component of a spatially distributed glacier runoff model is to monitor the spatial distribution of snow within the catchment (Braun, 1991). Snow depletion patterns can be derived from different remote sensing sources and provide a snapshot of the snow covered area on a particular day that can be compared with the model results. This method allows verification of the spatial distribution of snow but not the total storage of snow water equivalent (SWE). During the total modelling period from 1994 to 2009, different available remote sensing sources were used to compare the model results with observed snow cover distributions and to recalibrate the snow parameters (Table 2) if necessary. The first calibration date was the date of the only available orthophoto series of all Tyrolean glaciers (3 September 1997). A visual evaluation achieved accurate results, e.g. at Hintereisferner (Kirnbauer et al., 2009).

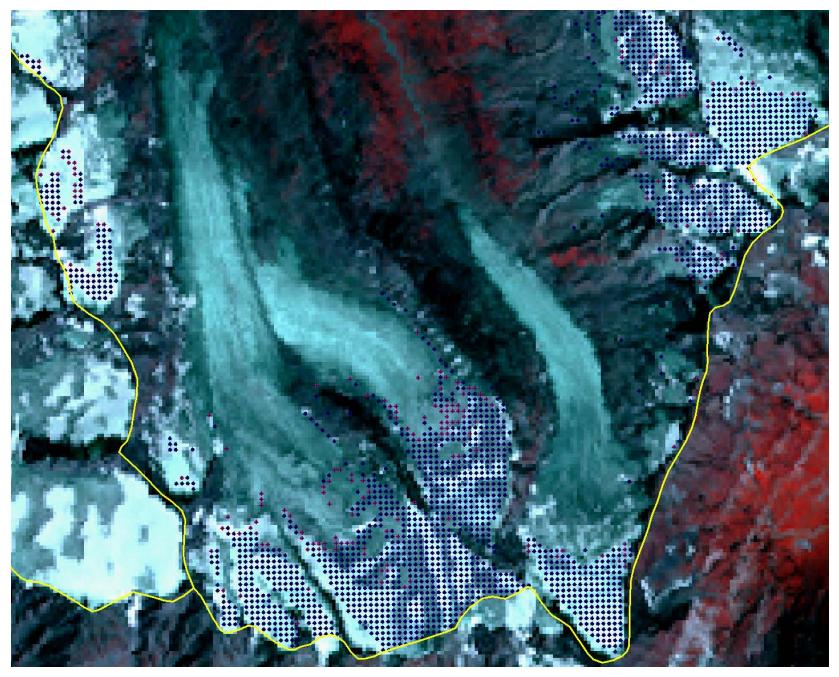

Fig. 2. Visual validation of the simulated snow cover on the glacier Gurglerferner on 13 September 1999 (dots $=$ SWE $>0$, blue $=$ snow, magenta $=$ firn).

As a next stage, Landsat Thematic Mapper datasets were used in the calibration process, they have a spatial resolution of $30 \mathrm{~m} \times 30 \mathrm{~m}$, which is a convenient source to compare with the spatial resolution of the model. The satellite pictures were primarily used to visually check the modelled snow cover. For the detection of snow-covered areas, band 4 (near infrared between $0.76-0.90 \mu \mathrm{m}$ ) of the Landsat TM dataset was used to produce false colour images where snow is emphasized. Due to snow grain-size differences, TM band 4 was found to show the greatest variability of the 6 reflective bands in spectral response in a glacierized Austrian area (Hall et al., 1987). Figure 2 gives an example of the glacier Gurglerferner only a few days before the flood event of 20 September 1999. To produce binary snow maps based on the information from the Landsat scenes, the Normalized Difference Snow Index (NDSI) was used (Dozier, 1989). The NDSI combines the green (band 2, $0.53-0.61 \mathrm{~km}^{2} \mathrm{~m}$ ) or the red channel (band 3, $0.63-0.69 \mathrm{~km}^{2} \mathrm{~m}$ ) with the mid infrared channel (band 5, 1.55-1.75 km² $\mathrm{m}$ ) and thus snow covered areas can be separated from clouds and snow free areas. As a threshold for the pixel value to border snow areas, a value of the calculated planetary albedo of 0.4 was used (Rott et al., 2007). After intersecting such a snow layer with the modelled layer of the corresponding date, the simulated snow cover can be validated. For this validation comparison an approach described in Klein and Barnett (2003) was used. Table 3 presents a confusion matrix comparing all valid cloudfree pixels between Landsat snow (data) and modelled snow (model). A pixel can be either true (snow in data and model; no snow in data and model) or false (snow in data and no snow in model; snow in model and no snow in data). With the accumulation of all pixels assigned to be true, an overall agreement [\%] can be calculated for each date and catchment. 

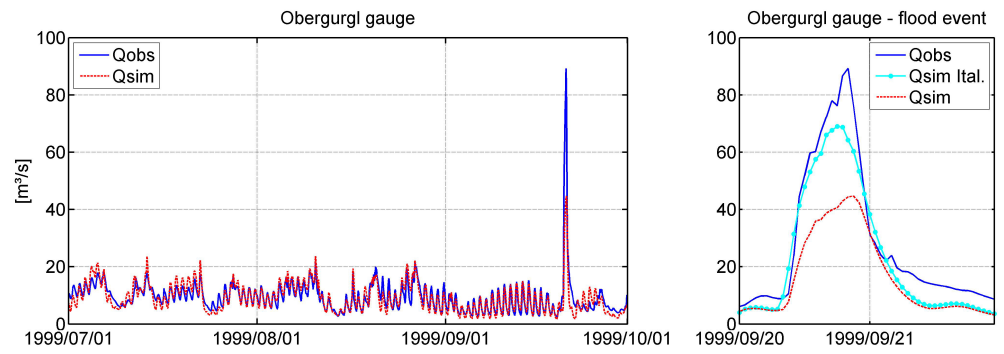

Fig. 3. Measured $\left(Q_{\text {obs }}\left[\mathrm{m}^{3} / \mathrm{s}\right]\right)$ and simulated $\left(Q_{\text {sim }}\left[\mathrm{m}^{3} / \mathrm{s}\right]\right)$ hydrographs of the Obergurgl gauge $\left(72 \mathrm{~km}^{2}\right)$ from 1 July until 30 September 1999 and a case study hydrograph with different precipitation input from an additional non-online station in Italy $\left(Q_{\text {sim }}\right.$ Ital. $\left.\left[\mathrm{m}^{3} / \mathrm{s}\right]\right)$.

Table 3. Confusion matrix comparing Landsat snow cover and modelled snow cover for the Obergurgl catchment on 30 June 2001.

\begin{tabular}{lccc}
\hline & \multicolumn{3}{c}{ SES } \\
& & Snow & No snow \\
\hline Landsat & Snow & $52 \%$ & $12 \%$ \\
& No snow & $8 \%$ & $28 \%$ \\
Overall agreement & \multicolumn{2}{c}{$80 \%$} & \\
\hline
\end{tabular}

Additionally, terrestrial photographs from single glaciers were used to verify the modelling results. Rectifying such photographs is time-consuming and limited to only a small investigation area. Therefore an alternative method was developed to contribute immediate snow cover information during the operational mode of the forecast system. Since digital elevation models can be visualized in 3-D by a GIS, this was used to display simulated snow patterns. Knowing the point from which the picture was taken, the 3-D-View of the geodata (snowcover, DEM, etc.) can be adjusted to the photograph and therefore distinct locations such as summits, being available in an underlying DEM (Digital Elevation Model) as well as in the picture, are used. Accordingly, observed and simulated snow patterns can be visually compared. This method is also useful for the available webcam data from Hintereisferner and the Oberbergbach catchment. An example of this method, showing snow cover extend at the end of the calibration period in September 2008, is presented in Kirnbauer et al. (2009) and Fig. 7 shows two examples from the validation period in 2009 .

\section{Results}

\subsection{Calibration and validation of runoff}

Figure 3 shows as an example the hydrograph of gauge Ober$\operatorname{gurgl}\left(72 \mathrm{~km}^{2}\right)$ during July to September 1999 . These months are normally the period with the highest flood potential in a year. The model shows a good ability to describe the average seasonal stream flow. In this example the model calculates only a slightly overestimated flow volume $(+2.3 \%)$. Figure 3 also shows the observed maximum flood in the total calibration period (20 September 1999). During this event the overall maximum flow (HHQ) at the Obergurgl gauge and one of the largest flows at Vent - Venterache gauge were observed. This event, and also any other event larger than HQ1, were taken into account for the calibration process. The calculated efficiencies of each separate flood event were plotted with respect to the measured peak flow $\left(Q_{\mathrm{MAX}, \mathrm{M}}\left[\mathrm{m}^{3} / \mathrm{s}\right]\right)$ in order to link the calibration quality to the events magnitude. In Fig. 4 all indicator results for the Vent - Venterache gauge $\left(165 \mathrm{~km}^{2}\right)$ are plotted. An acceptable correlation between the observed $\left(Q_{\mathrm{MAX}, \mathrm{M}}\left[\mathrm{m}^{3} / \mathrm{s}\right]\right)$ and simulated $\left(Q_{\mathrm{MAX}, \mathrm{S}}\left[\mathrm{m}^{3} / \mathrm{s}\right]\right)$ peak flows is shown with the exception of the largest measured flood event within the calibration period. For the 1999 event, the simulated peak flow (like in Fig. 3) is considerably underestimated.

For validation purposes, the runoff parameters were tested for their capability to describe floods at the three calibration gauging stations. At the Vent gauge, five events larger than a one-year flood event occurred during the validation period (Fig. 5). For all of these events the simulation results proved to be well calibrated. In Fig. 6 a hydrograph containing two consecutive peak flows larger than HQ1 is plotted, the parameterization fits particularly well for the two observed peak flows. During flood recession the simulated hydrograph underestimates the observation. Possible causes will be discussed later.

\subsection{Calibration and validation of snow cover}

The underestimated flood event of 20 September 1999 was also a topic in the validation of the snow coverage. In Fig. 2 the Gurglerferner is presented as a part of the basin of the Gurglerache gauge. In the false colour (IR) composite image snow is accentuated in blue, therefore snow and bare ice can be distinguished. Using the final snow parameters, the modelled snow cover of the total catchment shows a slight overestimation compared to the observed situation on 13 September 1999. Despite this the spatial distribution of the simulated snow depletion pattern correlates accurately to 
Table 4. Calculated overall agreements for all SES-catchments on 30 June 2001 and 12 June 2009; snow area or snow model is the catchments snow cover rate either assessed from the satellite image or calculated using SES. The 2001 data sets were used for calibration and validation, the 2009 data was used for validation only.

\begin{tabular}{|c|c|c|c|c|c|c|c|}
\hline \multirow{5}{*}{\multicolumn{2}{|c|}{$\begin{array}{r}\text { Date } \\
\text { Sensor } \\
\text { Landsat (Path/Row) } \\
\text { Cloud cover of scene } \\
\text { Solar zenith }\end{array}$}} & & \multicolumn{3}{|c|}{12 June 2009} \\
\hline & & \multicolumn{3}{|c|}{ Landsat 7} & \multicolumn{3}{|c|}{ Landsat 5} \\
\hline & & \multicolumn{3}{|c|}{$193 / 27$} & \multicolumn{3}{|c|}{$193 / 27$} \\
\hline & & \multicolumn{3}{|c|}{$15 \%$} & \multicolumn{3}{|c|}{$35 \%$} \\
\hline & & & 29.8 & & & 29.5 & \\
\hline \multicolumn{2}{|c|}{$\begin{array}{r}\text { Basins - calibration }(\mathrm{C}) \\
\text { validation }(\mathrm{V})\end{array}$} & $\begin{array}{c}\text { overall } \\
{[\%]}\end{array}$ & $\begin{array}{c}\text { snow area } \\
{[\%]}\end{array}$ & $\begin{array}{c}\text { snow model } \\
{[\%]}\end{array}$ & $\begin{array}{c}\text { overall } \\
{[\%]}\end{array}$ & $\begin{array}{c}\text { snow area } \\
{[\%]}\end{array}$ & $\begin{array}{c}\text { snow model } \\
{[\%]}\end{array}$ \\
\hline 1 Vent & $\mathrm{C}$ & 82 & 63 & 50 & 82 & 72 & 58 \\
\hline 2 Obergurgl & $\mathrm{C}$ & 80 & 64 & 60 & 79 & 73 & 56 \\
\hline 3 Gepatschalm & $\mathrm{C}$ & 73 & 67 & 40 & 81 & 72 & 56 \\
\hline 4 Oberbergbach & $\mathrm{C}$ & 75 & 56 & 67 & 78 & 62 & 52 \\
\hline 5 Pitze & $\mathrm{C}$ & 77 & 88 & 67 & 79 & 93 & 73 \\
\hline 6 Winnebach & $\mathrm{C}$ & 79 & 49 & 54 & 81 & 53 & 45 \\
\hline 7 Fischbach & V & 79 & 70 & 71 & 74 & 79 & 56 \\
\hline 8 Taschachbach & V & 70 & 70 & 41 & 75 & 77 & 54 \\
\hline 9 Sulzenaubach & V & 77 & 64 & 69 & 68 & 70 & 40 \\
\hline 10 Falbesonerbach & V & 76 & clouds & clouds & 79 & 44 & 39 \\
\hline 11 Fernaubach & V & 80 & 60 & 68 & 74 & 67 & 43 \\
\hline 12 Lüsenerbach & V & 89 & 58 & 51 & 88 & 57 & 47 \\
\hline 13 Jambach & $\mathrm{V}$ & 79 & 75 & 60 & 75 & 78 & 57 \\
\hline Mean & & 78 & 65 & 58 & 78 & 69 & 52 \\
\hline
\end{tabular}
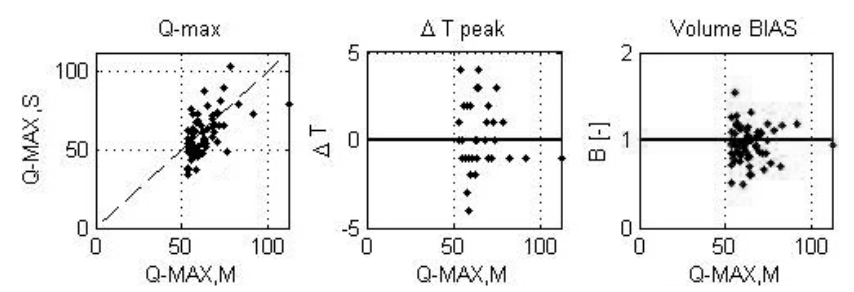

Fig. 4. Model efficiencies for calibration peak flows separated on the basis of the one-year recurrence interval at the Vent - Venterache gauge $\left(165 \mathrm{~km}^{2}\right)$. Left: measured peak flow $\left(Q_{\mathrm{MAX}, \mathrm{M}}\left[\mathrm{m}^{3} / \mathrm{s}\right]\right)$ vs. simulated peak flow $\left(Q_{\mathrm{MAX}, \mathrm{S}}\left[\mathrm{m}^{3} / \mathrm{s}\right]\right)$; middle: temporal shift of the peak flow $(\Delta T[\mathrm{~h}])$ vs. $\left(Q_{\mathrm{MAX}, \mathrm{M}}\left[\mathrm{m}^{3} / \mathrm{s}\right]\right)$; right: bias of the events discharge volume $(B[-])$ vs. $\left(Q_{\mathrm{MAX}, \mathrm{M}}\left[\mathrm{m}^{3} / \mathrm{s}\right]\right)$.

the observable snow in the satellite image. The simulation errors associated with the event occurring one week later must therefore be affected by other causes such as the meteorological input during the storm.

An available Landsat image for 30 June 2001 (i.e. before one of the main calibration floods in July 2001) was used to analyse the area-wide snow coverage of all SES-basins. For the aggregation of the snow cover distribution the NDSI was used. By intersecting the remotely-sensed snow layer with all of the modelled snow cover an overall agreement for each catchment on this date was calculated, as shown in Table 3
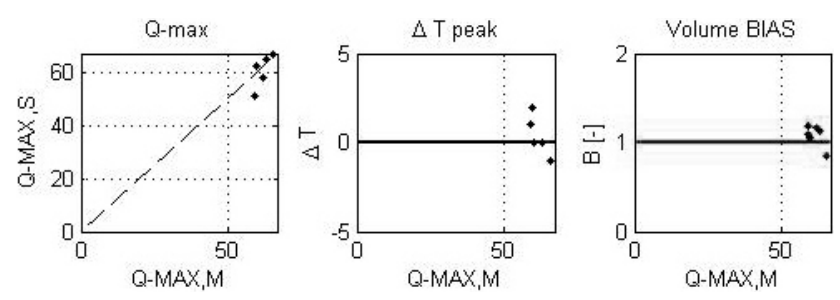

Fig. 5. Model efficiencies for validation peak flows separated on the basis of the one-year recurrence interval at the Vent - Venterache gauge $\left(165 \mathrm{~km}^{2}\right)$. Left: measured peak flow $\left(Q_{\mathrm{MAX}, \mathrm{M}}\left[\mathrm{m}^{3} / \mathrm{s}\right]\right)$ vs. simulated peak flow $\left(Q_{\mathrm{MAX}, \mathrm{S}}\left[\mathrm{m}^{3} / \mathrm{s}\right]\right)$; middle: temporal shift of the peak flow $(\Delta T[\mathrm{~h}])$ vs. $\left(Q_{\mathrm{MAX}, \mathrm{M}}\left[\mathrm{m}^{3} / \mathrm{s}\right]\right)$; right: bias of the events discharge volume ( $B[-])$ vs. $\left(Q_{\mathrm{MAX}, \mathrm{M}}\left[\mathrm{m}^{3} / \mathrm{s}\right]\right)$.

for Obergurgl. A mean overall agreement of $78 \%$ was evaluated for all basins with the final parameter set. Details for each catchment can be seen in Table 4, in this table, "snow area" means remotely sensed snow cover rate within the catchment and "snow model" means simulated snow cover rate within the catchment. During the calibration process more than half of the modelled basins were only sporadically or not at all investigated, such as the Lüsnerbach basin, nevertheless, this catchment achieved the highest agreement $(89 \%)$ with the remotely sensed snow cover. These validation catchments are marked with "V" in Table 4. 


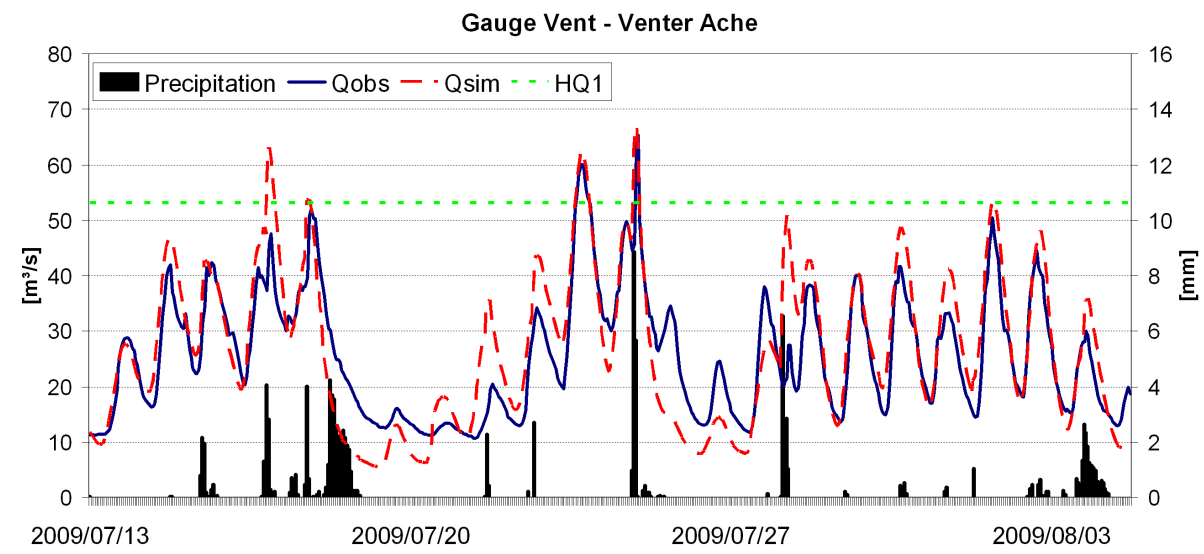

Fig. 6. Comparison of the observed $\left(Q_{\mathrm{obs}}\left[\mathrm{m}^{3} / \mathrm{s}\right]\right)$ and simulated $\left(Q_{\mathrm{sim}}\left[\mathrm{m}^{3} / \mathrm{s}\right]\right)$ hydrograph of the validation period at the Vent - Venterache gauge $\left(165 \mathrm{~km}^{2}\right)$, also including input precipitation $[\mathrm{mm} / \mathrm{h}]$.

The verification of the snow depletion patterns in 2009 was of special interest since they are the results of almost 15 continuously simulated hydrological years without a state and parameter correction during the run. A Landsat image of 12 June 2009 was therefore used to validate the quality of the simulated snow cover of all catchments. The snow cover distributions on this date compare well with the snow states in June 2001. Catchment-wise values of the overall agreement range between $68 \%$ and $88 \%$ for this date with a mean overall agreement of $78 \%$ for all SES areas. From the area-wide snow cover rate, $83 \%$ can be mapped by the model. For classifying these results, the work of Klein and Barnett (2003) was consulted. In this article, an overall agreement of $86 \%$ between two different remotely sensed snow map time series was classified as having a high correlation, and the differences between these maps can be traced back to different mapping algorithms. One of these methods used in their work is comparable to the here used NDSI. The NDSI was found to overestimate slightly when using the more coarse MODIS data. In our work, the NDSI snow maps also include portions of snow-free glacier tongues in at least two of the investigation areas. Only one catchment (Falbesonerbach) within the 2001 Landsat image was slightly affected by cloud coverage while the 2009 Landsat image was cloud free over the SES-basins.

\subsection{Transfer of parameter settings to ungauged catchments}

Because of high overall agreements between observed and modelled snow patterns the snow model parameters proved to be transferable. Basins which were not included in the calibration process also showed good agreements with the observed snow coverage. The combined calibration using snow patterns in addition to long term flow measurements was examined for three glacierized catchments (Vent, Obergurgl, and Gepatschalm). For these watersheds a uniform set of parameters was found, however, more than half of the glacierized catchments calculated within HoPI are ungauged. Mader and Kaser (1994) described the transfer of the parameters of a calibrated linear reservoir model from Vernagtferner to another glacierized basin in Austria (Silvretta). Melt rates were calculated using a physically-based glacier model including field measurements. Although the two catchments have a different ratio of glacierization and varying topographic characteristics they used the calibrated runoff parameters without any additional re-calibrations. The hourly variations of calculated runoff were found to correlate highly with the observed discharge rates. In a simulation period of 68 days between 10 July and 15 September 1991, the calculated total runoff volume was $101.2 \%$ of the measured value. For the SES-basin Fischbach (Table 1), runoff measurements are available since the beginning of 2007. The assessed discharge parameters from the three calibration catchments were applied to calculate the stream flow for this watershed in combination with the validated snow parameters. For comparing the simulation results with the literature, the runoff volume over a 68 days period between 10 July and 15 September 2007 was calculated and found to be $98.6 \%$ of the measured value. Over a period of two years $99.2 \%$ of the total discharge volume can be calculated with this parameter set. This demonstrates the accuracy of the validated parameters; therefore, the parameter set was transferred for the simulation of the ungauged glacierized basins within the forecast system.

\section{Discussion}

Blöschl et al. (1991) noticed that errors of the snowmelt routine are transferred to the runoff model when the calibration is based on runoff. Thus, considerable effort was taken to validate snow depletion patterns, particularly before flood events. Two area-wide snow cover states were validated, 


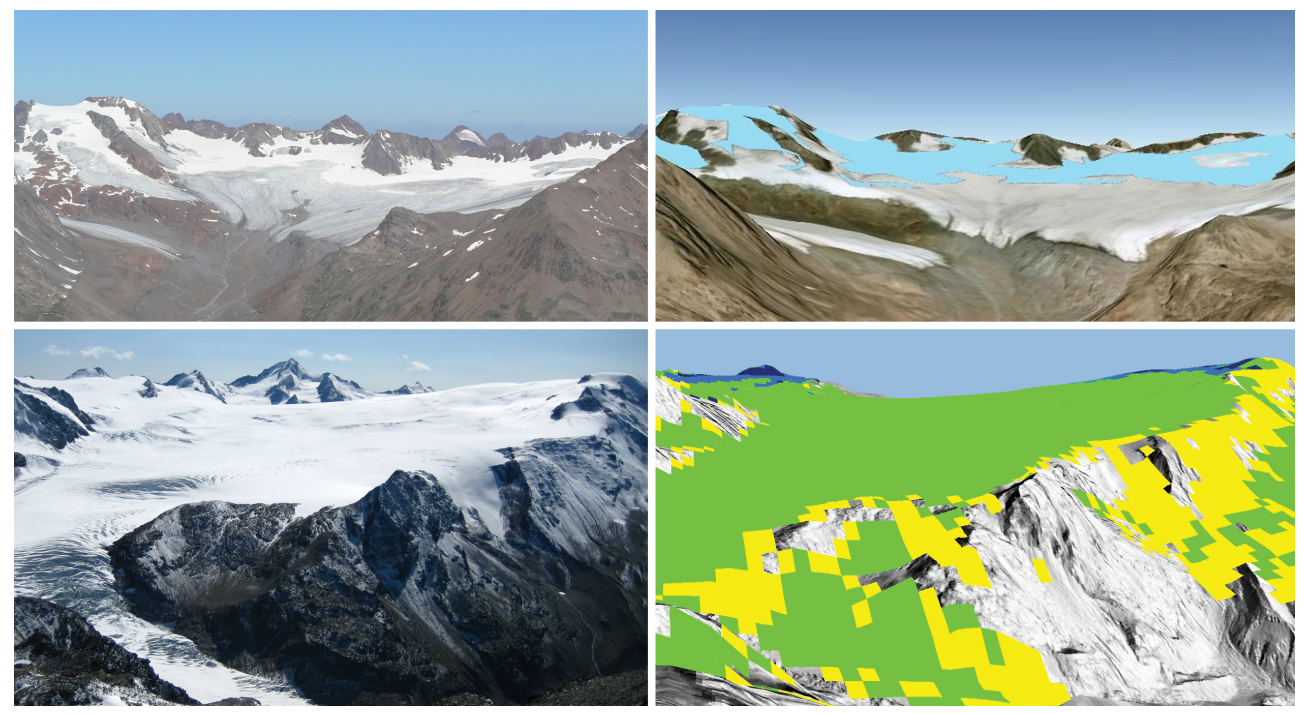

Fig. 7. 3-D comparison of observed and simulated snow patterns from 15 August 2009 at Vernagtferner illustrated using Google Earth (upper row); simulated classified snow cover from 3 September 2003 on the glacier Gepatschferner based on a laserscan DEM (lower row, SWE-values: yellow 0-10 $\mathrm{mm}$, green $10-100 \mathrm{~mm}$ and blue $>100 \mathrm{~mm}$ ).

including one which can be seen as representative for the initial state for the flood event in July 2001. Agreements of $78 \%$ between observed and modelled snow distribution were found for both dates. In 2009 all of the simulated catchments showed underestimated snow-cover rates, while in 2001 overestimated modelled snow-cover rates were calculated for five catchments. In 2001 an average underestimation of $7 \%$ was detected, in 2009 the average simulated snow cover was $17 \%$ lower than the observed one. Besides its influence on the flood event in 2001, the snow coverage in June, at the start of the ablation period of the glaciers, is in general an indicator for the characteristics of the melt season. For this period of the year the model proved its ability to simulate well agreeing snow cover distributions. For other catchment states, later in the ablation period, overall agreements have not yet been calculated because the discrimination of snow on a glacier is a more complex process where topographic corrections of the satellite data are needed. Although visual comparisons for snow patterns during the melt seasons showed acceptable correlations (e.g. Fig. 2 and example of Vernagtferner in Fig. 7, top left and right pictures), forthcoming works should also include a calculated agreement between observed and simulated snow coverage.

However, a photograph taken on 6 September 2009 after a period of precipitation in combination with cold temperatures shows an overestimation in the modelled snow coverage (Fig. 7, lower row). Consequently the simulated flow at the Gepatschalm gauge was lower than the observed one, such as can be seen during flood recession in Fig. 6. With this in mind, the underestimated flood event of 20 September 1999 was re-analysed (Fig. 3). The event sum of the interpolated model rain was $69 \mathrm{~mm}$. During calibration, only data from (later) online-available rain gauges of the forecast system station network were used, this network of stations is limited to the territory of Austria. Additionally, an Italian rain gauge was checked which is located only a few kilometres south of the Obergurgl catchment centre; at this gauge location the recorded rain sum during the storm was $101 \mathrm{~mm}$. Orographically-forced clouds from the south side of the Alpine main ridge caused intense rainfall in the nearby northern catchments e.g. Obergurgl and Vent (ZAMG, 2010). Therefore, the event was rerun using the hourly rainfall from the Italian station as the only input. In this run, the simulated flow reaches a peak value of $70 \mathrm{~m}^{3} / \mathrm{s}\left(+20 \mathrm{~m}^{3} / \mathrm{s}\right.$ compared to the original simulation) for the event. However, the measured peak flow is still underestimated by roughly $25 \%$, thus the changed rainfall input only partly explains the difference.

Additionally, the separation between snow and rain fall during the flood event was investigated. The method of calculating the snow-rain separation using a lower and an upper temperature threshold is rather sensitive to the quality of the meteorological measurements and the calculation of the temperature lapse rate. In HoPI a linear regression technique is used to determine a mean temperature lapse rate. Meteorological stations are situated between 700 and $2800 \mathrm{~m}$ a.s.l., but none of the available stations are located in the glacierized region above $3000 \mathrm{~m}$, therefore, temperature has to be extrapolated for calculations with SES. Both methods, linear regression and the extrapolation of the temperature, introduce possible modelling errors as demonstrated by Rinderer et al. (2008). During the flood event of 1999 the input temperature decreased to a value where snowfall had to be expected in a large part of the catchment. The modelled snow cover within the catchment of Obergurgl increased 
from $28 \%$ at the start of the event to $70 \%$ after the flood event. An overestimated snow accumulation in the model is a possible explanation for the underestimated flows modelled during the event itself. Because of the lack of comparable data, the hypothesis of overestimated snow coverage cannot be verified by aerial photographs or satellite images after the event. However, overestimated melt rates in the simulations for days after the event also indicate an overestimated storage of snow water equivalent (Fig. 3). This was also seen in the catchment of the Gepatschalm gauge during the validation period. As shown in Fig. 7 with a pictured overestimated snow cover state, the associated simulation hydrograph was primarily underestimated and later also influenced by overestimations due to increased melt rates. Thus, remaining errors in flood simulation seem to be additionally induced by the imprecise simulation of the temperature distribution and the resulting snow quantities introduced in the model. For further investigations on this subject, remotely-sensed information of the alpine catchment states could be an important data source for clarification.

\section{Conclusions}

In this study, considerable efforts were made to simulate the spatial distribution of snow correctly since glaciers can have a major impact on the formation of floods. Visual and calculated comparisons of observed and simulated snow-depletion patterns showed high agreements, also when investigating the initial states of flood events. Following a continuous simulation run of 15 hydrological years, $78 \%$ overall agreement between area-wide snow coverage and the relevant simulation results can be calculated. Non-calibrated catchments also showed good agreements for the snow cover validation. Thus, calibrated parameters of the physically-based melt approach of the Snow- and Icemelt Model (SES) were found to be transferable. Runoff parameters were also found to be applicable for a non-calibrated catchment and were later transferred to ungauged catchments within the flood forecast system.

However, underestimated model results during particular flood events were discussed. These imperfections in peak flow simulations are influenced by the meteorological input data. Overestimated snow cover caused by imprecise temperature processing was shown to be the reason of inaccurate flow simulations. Further investigations on the propagation of station-based temperature values to the catchment areas are required for further improvements. Non-representative rain gauge locations tend to result in incorrect precipitation and temperature input; therefore the grid of online available stations is currently extended particularly to the high mountain regions and also to neighbouring countries, e.g. Italian station data will soon be online provided to the Tyrolean hydrological service.
Acknowledgements. This work has been undertaken within the frame of the alpS Project "1.1 abc Flood Forecasting System for the Tyrolean Inn - A hybrid hydraulic/hydrologic model for improving flood forecasts". The authors would like to thank the federal state of Tyrol, the Austrian Research Promotion Agency (FFG), and the TIWAG - Tiroler Wasserkraft AG who support the project. Thanks to two anonymous reviewers for their helpful comments to the manuscript.

Edited by: A. Wahren, F. Tavares Wahren, and K.-H. Feger Reviewed by: H. Bormann and another anonymous referee

\section{References}

Achleitner, S., Rinderer, M., and Kirnbauer, R.: Hydrological modelling in alpine catchments: sensing the critical parameters towards an efficient model calibration, Water Sci. Technol., 60(6), 1507-1514, doi:10.2166/wst.2009.488s, 2009.

Asztalos, J., Kirnbauer, R., Escher-Vetter, H., and Braun, L.: A distributed energy balance snow and glacier melt model as a component of a flood forecasting system for the Inn river, Proceedings of the Alpine*Snow*Workshop, Munich, October 5-6, 2006, Germany, Berchtesgaden, Berchtesgaden National Park research report, Nr. 53, 9-17, 2007.

Asztalos, J.: Ein Schnee- und Eisschmelzmodell für vergletscherte Einzugsgebiete, Master's thesis, Vienna University of Technology, Austria, 2004.

Blöschl, G., Kirnbauer, R., and Gutknecht, D.: Assessment of snowmelt simulations in Alpine terrain on the basis of depletion patterns, T. Am. Geophys. Un., 70(43), p. 1113, 1989.

Blöschl, G., Kirnbauer, R., and Gutknecht, D.: Distributed snowmelt simulations in an alpine catchment -1 . Model evaluation on the basis of snow cover patterns, Water Resour. Res., 27(12), 3171-3179, 1991.

Blöschl, G. and Kirnbauer, R.: An analysis of snow cover patterns in a small Alpine catchment, Hydrol. Process., 6, 99-109, 1992.

Braun, L. and Weber, M.: Droht im nächsten Sommer Hochwasser vom Gletscher?, Rundgespräche der Kommission für Ökologie der BAdW, 1-21, 2002.

Braun, L. N.: Modelling of the snow-watar equivalent in the mountain environment, in: Snow, hydrology and forests in high alpine areas, edited by: Bergmann, H., Lang, H., Frey, W., lssler, D., and Salm, B., Proc. Vienna Symp., IAHS Publ no. 205, 3-17, 1991.

Braun, L. N.: Simulation of snowmelt-runoff in lowland and lower alpine regions of Switzerland. Zürcher Geographische Schriften, 21, 166 pp., 1985.

Dozier J.: Spectral Signature of Alpine Snow Cover from the Landsat Thematic Mapper, Remote Sens. Environ., 28, 9-22, 1989.

Escher-Vetter, H., Braun, L., Siebers, M., and Weber, M.: Water balance of the Vernagtferner high aline basin based on longterm measurements and modelling, Landschaftsökologie und Umweltforschung, TU Braunschweig, 48, 19-32, 2005.

Escher-Vetter, H.: Der Strahlungshaushalt des Vernagtferners als Basis der Energiehaushaltsberechnung zur Bestimmung der Schmelzwaserproduktion eines Alpengletschers, Münchener Universitäts-Schriften, Fachber. Physik - Univ. München Met. Inst., Wiss. Mitt. Nr. 39, 117 pp., 1980 (in German). 
Fischer, A.: Glaciers and climate change: Interpretation of 50 years of direct mass balance of Hintereisferner, Global Planet. Change, 71(1-2), 13-26, 2010.

Haiden, T., Kann, A., Stadlbacher, K., Steinheimer, M., and Wittmann, C.: Integrated Nowcasting Through Comprehensive Analysis (INCA) - System Overview. ZAMG report, 49 pp., 2007.

Hall, D. K., Ormsby, J. P., Bindschadler, R. A., and Siddalingaiah, H.: Characterization of snow and ice reflectance zones on glaciers using Landsat Thematic Mapper data, Ann. Glaciol., 9, 104-108, 1987.

Hock, R.: Distributed temperature-index ice- and snowmelt model including potential direct solar radiation, J. Glaciol., 45, 101111, 1999.

Jasper, K., Gurtz, J., and Lang, H.: Advanced flood forecasting in Alpine watersheds by coupling meteorological observations and forecasts with a distributed hydrological model, J. Hydrol., 267, 40-52, 2002.

Kasten, F. and Czeplak, G.: Solar and terrestrial radiation dependent on the cloud amount and type of cloud, Sol. Energy, 24, 177-189, 1980.

Kirnbauer, R. und Schönlaub H.: Vorhersage für den Inn, Wiener Mitteilungen, 199, 69-84, 2006.

Kirnbauer, R., Achleitner, S., Schöber, J., Asztalos, J., and Schönlaub, H.: Hochwasservorhersage Inn: Modellierung der Gletscherabflüsse, Mitteilungsblatt des Hydrographischen Dienstes in Österreich, Nr. 86, 109-130, available at: http://publikationen.lebensministerium.at/publication/ publication/view/3222/28627 (last access: 23 May 2010), 2009.

Klein, A. G. and Barnett, A. C.: Validation of daily MODIS snow cover maps of the Upper Rio Grande River Basin for the 20002001 snow year, Remote Sens. Environ., 86, 162-176, 2003.

Kleindienst, H.: Erweiterung und Erprobung eines anwendungsorientierten hydrologischen Modells zur Gangliniensimulation in kleinen Wildbacheinzugsgebieten, Master's Thesis, Institut für Geographie, Ludwig Maximilians Universität München, Germany, 1996.

Lambrecht, A. and Kuhn, M.: Glacier changes in the Austrian Alps during the last three decades, derived from the new Austrian glacier inventory, Ann. Glaciol., 46, 177-184, 2007.

Mader, M. and Kaser, G.: Application of a linear reservoir model to the discharge of a glacierized basin in the Silvretta mountains, Zeitschrift für Gletscherkunde und Glazialgeologie, 30, 125-140, 1994.

Nash, J.: A unit hydrograph study with particular reference to British catchments, Proc. Inst. Civ. Eng., 17, 249-282, 1960.

Reichel, G., Fäh, R., and Baumhackl, G.: FLORIS-2000: Ansätze zur 1.5D-Simulation des Sedimenttransportes im Rahmen der mathematischen Modellierung von Fließvorgängen, in: Symposium: Betrieb und Überwachung wasserbaulicher Anlagen, Graz, 19.-20.10.2000, edited by: Heigerth, G., Eigenverlag Inst. f. Wasserbau u. Wasserwirtschaft, Techn. Univ. Graz, Germany, 485-494, 2000.
Rinderer, M., Achleitner, S., Asztalos, J., and Kirnbauer, R.: Sensitivity analysis of laps rate and corresponding elevation of snowline - limited data availability and ist impact on snow and glacier melt, in: Proceedings of the 4th International Symposium on Flood Defence, 5th-8th of May, Toronto, Institute for Catastrophic Loss Reduction (ICLR) (Ed.), Canada, 2008.

Rott, H., Nagler, T., Malcher, P., and Bippus, G.: Modelling Mass Balance of Glaciers using Satellite Data, Proc. of ENVISAT Symp., 6 pp, 2007.

Steinacker, R.: Die alpinen Hochwasserereignisse des Sommers 1987, Österreichische Wasserwirtschaft, Jahrgang 40, Heft 5/6, 1988.

Strasser, U., Corripio, J., Brock, B., Pellicciotti, F., Burlando, P., and Funk, M.: Spatial and temporal variability of meteorological variables at Haut Glacier d'Arolla (Switzerland) during the ablation season 2001: Measurements and simulations, J. Geophys. Res., 109, D03103, doi:10.1029/2003JD003973, 2004.

US Army Corps of Engineers: Snow hydrology, Summary report of the snow investigations, North Pacific Division, Portland (Oregon), 1956.

Verbunt, M., Walser, A., Gurtz, J., Montani, A., and Schär, C.: Probabilistic Flood Forecasting with a Limited-Area Ensemble Prediction System: Selected Case Studies, J. Hydrometeorol., 8, 897-909, doi:10.1175/JHM594.1, 2007.

Viviroli, D., Zappa, M., Schwanbeck, J., Gurtz, J., and Weingartner, R.: Continuous simulation for flood estimation in ungauged mesoscale catchments of Switzerland - Part I: Modelling framework and calibration results, J. Hydrol., 377(1-2), 191-207, 2009.

Weber, M.: Einfluss der Luftfeuchte auf die Ablation des Vernagtferners - Ergebnisse der Feldmesskampagnen HyMEX98 und HyMEX2000, Beitrag anlässlich der Tagung DACH-MT 2001 in Wien, Kommission für Glaziologie der BAdW, 2001.

Weber, M., Braun, L., Mauser, W., and Prasch, M.: The relevance of glacier melt for the upper Danube River discharge today and in the future, Mitteilungsblatt des Hydrographischen Dienstes in Österreich, Nr. 86, 1-29, 2009.

ZAMG, Zentralanstalt für Meteorologie und Geophysik: Witterungsübersicht, available at: http://www.zamg.ac.at/fix/klima/ wiewars09-99.pdf (last access: 23 May 2010), September 1999.

Zappa, M., Pos, F., Strasser, U., Warmerdam, P., and Gurtz, J.: Seasonal Water Balance of an Alpine Catchment as Evaluated by Different Methods for Spatially Distributed Snowmelt Modelling, Nord. Hydrol., 34(3), 179-202, 2003. 